The Lewis Hanke Prize (to support the transformation of a dissertation into a book):

Celso Castilho (Vanderbilt University), "Remaking Nation and Citizenship in Northeastern Brazil: The Politics of Antislavery in Pernambuco, 1866-1893."

The Lydia Cabrera Award (to support research on Cuba between 1492 and 1868):

Joanna Elrick (Vanderbilt University) and Daniel Rood (University of California, Irvine)

Distinguished Service Award (conferred annually upon a person whose career in scholarship, teaching, publishing, librarianship, institutional development of other fields demonstrates significant contributions to the advancement of the study of Latin American history in the United States):

Friedrich Katz (University of Chicago)

\title{
Professional News
}

President Barack Obama has appointed Rolena Adorno to membership on the National Council on the Humanities, the advisory board to the National Endowment for the Humanities (NEH). Dr. Adorno, an award-winning scholar of Colonial Spanish American literature and the nineteenth-century origins of Hispanism in the United States, is the Reuben Post Halleck Professor of Spanish and Chair of the Department of Spanish and Portuguese at Yale University. Until her appointment to the Council, Dr. Adorno had also been serving as a Senior Editor of this journal. The editors thank her for her contributions and offer their congratulations on her appointment.

\section{BoOKS IN BRUEF}

In the past few years, many presses have published translations of primary sources from Latin American history. Generally intended for classroom use, these works vary greatly in utility, but do provide options for bringing the events of the past to life. Four recent contributions focus on the colonial period, three from the sixteenth century and one from the scventeenth. Perhaps the text best known to students of colonial Latin America is Bernal Díaz del Castillo's The True History of the Conquest of New Spain. A recent addition to the long list of editions of this work has been published by the University of New Mexico Press in 2008, edited and with an introduction by David Carrasco. Like others, this is an abridgement of the original, designed to be more accessible to readers, but this new edition differs from the start by removing the word "True" from the title. In addition, the book contains eight essays to help the reader understand the various levels of the work and the material it contains. Carrasco is the author of five of these. Other authors are Rolena Adorno, Karen Viera Powers, and Sandra Messinger Cypess. Most refreshingly, in this edition Carrasco accepts that Díaz del Castillo was not an impartial observer, detachedly 
recounting the events of his youth, but rather a passionate, sometimes witty, sometimes acerbic narrator who had his own agenda to support in recounting the events of the conquest. Carrasco also includes material from the period following the fall of Tenochtitlan. This provides the reader with a more nuanced view of the effects of the conquest. Rather than a definitive Spanish triumph, the reader sees that the Spanish had their own internal squabbles and that the job of pacification did not end with the fall of the Aztec capital.

In a different vein, Kathleen Ann Myers has published a work entitled Fernández de Oviedo's Chronicle of America (Austin: University of Texas Press, 2007). Unlike the other works here, this is not a translation and edition of a primary source, but rather an analysis of Oviedo's Historia general y natural de las Indias. It does, however, contain 36 pages of excerpts translated from the original, along with 81 pages of illustrations taken from various editions of the work. The core of the book is a series of essays in which Myers analyzes Oviedo's history from various perspectives, including Oviedo's role as eyewitness and reporter, actor and autobiographer, the presentation of women in the text, the multiple realities of the Cortés expedition, and the representation of natives in Oviedo's work. Myers sees Oviedo as pursuing two goals: to be a faithful servant of the crown and a credible witness to the events he narrates. These two principles color all that he does.

Roughly contemporaneous with Oviedo, Hans Staden wrote his account of captivity in Brazil in the mid-sixteenth century. Duke University Press has recently published an edition entitled Hans Staden's True History: An Account of Cannibal Captivity in Brazil (2008), edited and translated by Neil L. Whitehead and Michael Harbsmeier. Staden, who served in a Portuguese coastal fort in Brazil, was captured while in the interior and held for nine months by the Tupinambá. The book is a critical edition, which includes most of the original illustrations from the published sixteenth-century original. It also contains an introduction, which places the work in its context. The book has become a cornerstone for discussion concerning native practices of cannibalism, but at the same time it is one of the earliest accounts available describing Brazil. Thus Whitehead and Harbsmeier seek to ransom the book from its place in the debate over cannibalism and place it rather within the literature of European contact with the native peoples of the Americas. The introduction also traces the publication history of the book and how it has figured in debates across the years.

Bernado de Vargas Machuca was an experienced military man who in 1599 published what has been described as a manual for conquerors. A new edition of the book, The Indian Militia and Description of the Indies, translated by Timothy F. Johnson, edited and with an introduction by Kris Lane, also has been published by Duke University Press (2008). Vargas Machuca wrote his treatise, which consists of four parts, with the idea that there were still worlds to conquer. The first part deals with military issues and the features of a commander. The second part looks at armaments, medicines, and munitions. The third part covers the behavior of soldiers and how to proceed under various situations of climate and topography. The last part looks at the aftermath of war: making peace, founding towns, and dealing with peaceful natives. The work also includes a description of South America, focusing mostly on New Granada. This quirky and engaging book is a unique and fascinating source that allows students into the mind of a particular type of Spaniard. 
Don Juan de Palafox y Mendoza was one of the most controversial figures of seventeethcentury Mexico. He served as visitador, bishop of Puebla, and ultimately interim viceroy. He was a dedicated royal servant who angered many members of religious orders when he insisted that they submit to his supervision. When the Jesuits refused, he began to impose the ecclesiastical tax (tithe) on their estates, arguing that only religious establishments recognized by the bishop were exempt. Palafox also published an important, short work regarding the natives of New Spain. A new version of the text, Virtues of the Indian/Virtudes del Indio, translated and edited by Nancy H. Fee with an introduction by Alejandro Cañeque, was published by Rowman and Littlefield in 2009. This is a fascinating work, largely unknown except by specialists in the period. The text is presented in both Spanish and English with the translation facing the original throughout. In addition, Fee has written a very complete biographical essay-a very good introduction to the text and period.

All of these books can serve as supplements to colonial history courses. Each is a solid contribution in its own right. What is most interesting is the appearance of little-known texts, once only the bailiwick of experts in the field, which are now being offered in edited and translated versions for use in the classroom. While one might wonder whether we really need a new translation of Bernal Díaz, having access to Vargas Machuca and Palafox is a treat indeed.

State University of New York, Potsdam

JOHN F. SCHWALLER

Potsdam, New York

Spain, Europe and the Wider World, 1500-1700. By J. H. Elliott. New Haven: Yale University Press, 2009. Pp. xx, 322. Figures Notes. Index. $\$ 38.00$ cloth.

In this collection of 14 engaging conference papers, J.H. Elliott presents an erudite lifetime of intellectual fascination with a "quartet of worlds too often compartmentalizedthe European and the American, the British and the Hispanic" (p. xix). After a preface that orients the reader to his scholarly philosophy, Elliott delivers a tripartite text. Part 1 addresses Europe's fragmentary nature during the early modern period, with a focus on Britain and Spain as quintessential competitors and emulators of one another. The author's discussion of European composite monarchies, such as the Spanish Habsburg Dynasty, is especially intriguing as it delves into the deep-seated tension between the state's desire for political unity and Europeans' traditional sense of family and patrimony. Part 2 artfully explores the wider world, including the overseas expansion of the European powers, Spain's initial perception of and subsequent disillusionment with the Americas, the British exclusionary and Spanish inclusionary approaches to indigenous populations, and the eclipse of empires in the Americas. In a particularly enlightening chapter, Elliott delves into Spaniards" "dawning and often uncomfortable awareness that America was different" ( $p$. 193 ) and creoles' assertion that "they were Americans, neither more nor less" (p. 210). Part 3 of Elliott's text is an eclectic study of European courtly society and the Spanish Golden Age artwork of El Greco and Velázquez. Through the lens of El Greco's life, the author evaluates the Mediterranean encounters of the Latin West, Greek Orthodox East, and Islamic civilization. In sum, scholars, students, history aficionados, and even policy- 